\title{
Sustainable medicine: good for the environment, good for people
}

October 2010 saw the Royal College of General Practitioners run its annual conference under the banner of 'Sustainable Primary Care'. Who would have predicted 10 years ago that issues of sustainability would have migrated from the green fringes to the mainstream of medical politics? Internationally, doctors are becoming increasingly mindful of the carbon costs of care and the health impacts of the twin demons of climate change and peak oil.1,2 Yet the profession remains pretty vague about what sustainable medicine might look like and why it is important. Does it represent any sort of fundamental change to medical practice or is it about continuing to do the same sort of stuff with a closer eye on the recycling bin?

Most of us have a general sense of the global situation. To rehearse, the burning of fossil fuels has caused the amount of carbon dioxide in the atmosphere to rise from 280 parts per million (ppm) in preindustrial times to $380 \mathrm{ppm}$ today. Only a very few sceptics dispute this and the fact that $\mathrm{CO}_{2}$, a greenhouse gas (GHG), was associated with global warming of some $0.8^{\circ}$ Celsius over the 20th century. ${ }^{3}$

What is harder to be sure about is the future course of global warming given the variety of feedback loops that broker the climate. For instance, as the earth heats, more water vapour enters the atmosphere forming additional cloud. Earth scientists are uncertain whether extra cloud will cool the earth (by absorbing incoming UV) or warm it (by trapping heat like a duvet). ${ }^{4}$

We can't be sure exactly what will happen to global temperature but if our predictive models are right, or even half right, the impact of climate change on human health will be enormous. ${ }^{5}$ In these circumstances it seems apt to deploy the precautionary principle. For the developed world the chief impacts will not be encroaching malaria or heat shock in the sweltering metropolis: for the West, the biggest challenge will be the arrival of people from parts of the world rendered uninhabitable by the combined effects of water scarcity, ${ }^{6}$ rising sea-levels, and the inevitable (and some would say already prevalent) armed conflict over diminishing resources. The earth's poorer nations are much less well positioned to buffer themselves from the effects of major climatic shifts ${ }^{7}$ and so will be most affected, despite themselves producing relatively little GHG.

It is this sort of doomsday reasoning that has triggered the introduction of targets for GHG emissions in most developed nations. In the UK these have come closer to home with the government's Carbon Reduction Commitment Energy Efficiency Scheme which requires all large UK organisations, including many NHS trusts, to publish their energy usage and be penalised for using too much and rewarded for efficiency gains This sort of policy is essential if we are to approach the UK government's target of an $80 \%$ reduction in GHG by 2050, a target which at present seems the stuff of dreams. The NHS launched its own carbon reduction programme in January $2009 .{ }^{8}$

This agenda, while interesting, may seem remote from the daily work of primary care. But while the news so far has been sobering if not depressing, the impacts of sustainable thinking on medicine are surprisingly upbeat. As we reduce our carbon consumption we simultaneously reduce the many deleterious effects of the fossil fuel-based economy on health. For example, by walking and cycling instead of driving we reap tangible benefits in terms of physical and mental health. ${ }^{9,10}$ By eating food, mainly plant-based, that relies less on oilbased fertilisers and pesticides and is less processed and packaged, we cut carbon and increase our chances of a healthy diet. ${ }^{11}$ These 'virtuous cycles' suggest that what is good for the earth is also good for humans.
Diet and exercise are examples of a wider call to work with what systems theorists would call 'resilience'. ${ }^{12}$ A resilient system is one in which the component parts are an effective communication through feedback loops of various types. As a result, when challenges emerge the system is capable of responding robustly rather than collapsing or developing dependence. Non resilience is when feedback signals are ignored and we see this in the environment (for example, loss of biodiversity) and in human health (for example, when a person with asthma continues to smoke).

Developing health systems that promote resilience is a huge but necessary challenge. Because of the links with climate change, a resilient system is of necessity in a low carbon system. Thus we should be interested in treatment options that are themselves low carbon. In the future, GPs may wish to make judicious use of telephone consultations to avoid unnecessary travel or understand the carbon costs of various pharmaceutical options (responsible for about $20 \%$ of the NHS carbon footprint). GPs are valued and trusted as focal points in their communities and so have real influence as exemplars of low-carbon living.

Hospitals are expensive, both fiscally and in terms of their carbon costs. The sustainability and quality improvement agendas are closely wedded to initiatives to keep patients out of hospitals by improving the resilience of home support - including the nurture of statutory and voluntary services. Care at the end of life can be particularly expensive and resource intensive. The role of GPs to empower patients to choose the end of life care they want, which is often at home rather than in hospital, can reduce these financial ${ }^{13}$ and environmental costs at the same time as increasing the appropriateness and dignity of care. 
The recent White Paper from the UK government, Equity and Excellence: Liberating the NHS, gives GPs in England and Wales a once in a generation opportunity to make a sophistocated response to these challenges rather than simply trying to balance the books. The commissioning choices that they make need to be aimed not only at delivering effective patient care, but also doing this in ways that minimise the impact that high carbon health care has on the long-term health of our society. We have a duty of care for tomorrow as well as for today.

Most people think of sustainability measures in medicine as part of a wider societal strategy to reduce carbon emissions and prevent global warming. The good news is that, in addition, the measures we might adopt to help the ailing environment are, in almost every case, of simultaneous benefit to human health, for instance with respect to obesity, diabetes, coronary heart disease, and mental wellbeing. That there are many unknowns in the climate equation should not dissuade us, as managing uncertainty is probably what we do best. As GPs we have a huge opportunity to broker the transition to a low-carbon healthcare system through our personal choices, our interactions with individual patients, and through the policies we create and adopt.

\section{Trevor Thompson,}

GP and Consultant Senior Lecturer in General Practice, Academic Unit of Primary Health Care, School of Social and Community Medicine, University of Bristol, Bristol.

\section{Tim Ballard,}

GP and RCGP Sustainability Lead, The Old School Surgery, Great Bedwyn.

\section{Provenance}

Commissioned, not externally peer reviewed.

\section{REFERENCES}

1. Lim V, Stubbs JW, Nahar N, et al. Politicians must heed health effects of climate change. Lancet 2009; 374(9694): 973.

2. Raffle AE. Oil, health, and health care. BMJ 2010; 341: DOI: 10.1136/bmj.c4596.

3. Intergovernmental Panel on Climate Change. IPCC Fourth Assessment Report: Climate Change 2007 (AR4). Geneva, Switzerland: IPCC, 2007. http://www.ipcc.ch/ (accessed 24 Nov 2010).

4. The Royal Society. Climate change: a summary of the science. London: The Royal Society, 2010.

5. Costello A, Abbas M, Allen A, et al. Managing the health effects of climate change: Lancet and University College London Institute for Global Health Commission. Lancet 2009; 373(9676): 1693-1733.

6. Vörösmarty CJ, McIntyre PB, Gessner MO, et al. Global threats to human water security and river biodiversity. Nature 2010; 467(7315): 555-561.

7. Tang KK, Petrie D, Rao DS. The income-climate trap of health development: a comparative analysis of African and Non-African countries. Soc Sci Med 2009; 69(7): 1099-1106.

8. NHS Sustainable Development Unit. Saving carbon, improving health. NHS carbon reduction strategy for England. Cambridge: NHS Sustainable Development Unit, 2009. http://www.sdu.nhs.uk/publicationsresources/3/NHS-Carbon-Reduction-Strategy/ (accessed 2 Dec 2010).

9. Rissel CE. Active travel: a climate change mitigation strategy with co-benefits for health. NS W Public Health Bull 2009; 20(1-2): 10-13.

10. Woodcock J, Edwards P, Tonne C, et al. Public health benefits of strategies to reduce greenhouse-gas emissions: urban land transport. Lancet 2009; 374(9705): 1930-1943.

11. Ornish D. Mostly plants. Am J Cardiol 2009; 104(7): 957-958.

12. Meadows DH. Thinking in systems: a primer. London: Earthscan, 2009.

13. Molloy DW, Guyatt GH, Russo R, et al. Systematic implementation of an advance directive program in nursing homes: a randomized controlled trial. JAMA 2000; 283(11): 1437-1444.

DOI: 10.3399/bjgp11X548875

ADDRESS FOR CORRESPONDENCE

Trevor Thompson

Academic Unit of Primary Health Care, School of Social and Community

Medicine, University of Bristol,

25 Belgrave Road, Bristol BS8 2AA.

E-mail: trevor.thompson@bris.ac.uk 